\title{
NEW APPROACHES FOR CONTROLLING TOMATO LEAFMINER, TUTA ABSOLUTA (MEYRICK) IN TOMATO FIELDS IN EGYPT
}

\author{
KHIDR, A.A. ${ }^{1}$, S. A. GAFFAR ${ }^{2 *}$, MAHA S. NADA ${ }^{1}$, \\ A. A. TAMAN ${ }^{1}$ and FATHIA A. SALEM ${ }^{1}$ \\ 1. Plant Protection Research Institute, ARC, Dokki, Giza. \\ 2. Central Laboratory of Organic Agriculture, ARC, Giza, Egypt. \\ *Corresponding author. Email: saad_bio_organic@yahoo.com
}

(Manuscript received 2 September 2012)

\begin{abstract}
Control methods were carried in Baltiem district, Kafrel-Sheikh Governorate from times during both Spring and Summer plantations, 2012. The efficacy of these control methods was recorded on the basis of reduction percentage in the larvae after periods of 2, 5, 7, 10 days from each application. The obtained results revealed that the highly increase in the reduction was occurred in Summer plantation verification with the number of larvae in Spring plantation. Based on reduction percentages in the number of larvae, the efficacy of the tested treatments could be descendingly arranged as follows Bacillus thuringiensis + Neem, $B$. thuringiensis + Trichogramma evanescens + mass trapping, $B$. thuringiensis + Trichoderma harzianum, $T$. harzianum + Neem, $T$. harzianum + mass trapping and $T$. evanescens + Neem. The corresponding value were $91.88,90.18,87.89,85.69,80.75$ and $84.82 \%$ for the above treatments, during Summer plantation and $88.49,86.03,84.78,83.01,79.88$ and $82.82 \%$ during Spring plantation. On the other hand, using baited traps of males moths using synthetic sex pheromones recorded the highest relative percentage were 10.91 and $10.76 \%$ in Spring and Summer plantation, respectively. Where the lowest one recorded 2.74 and $2.71 \%$ in Spring and Summer plantation. The highest healthy yield production recorded 9.555 ton/feddan in case of using $B$. thuringiensis + Neem, whereas the lowest healthy yield production recorded 5.580 ton/feddan when using $T$. evanescens + Neem. The corresponding general means of cost benefit 3317 and 1589 L.E/feddan, respectively. On the other hand, the healthy yield production in the untreated plot recorded 1.555 ton/ feddan.

Key words: Tuta absoluta, sex attractant pheromones, microbial insects, botanical extracts, Trichogramma.
\end{abstract}

\section{INTRODUCTION}

Egypt is considered one of the important tomato producer in the world (WPTC, 2011). Tomato leafminer, Tuta absoluta (Meyrick) (Gelechiidae: Lepidoptera), is an invasive pest causing severe loss for tomato production in many countries either in open field or green houses. Severely attacked tomato fruits lose their commercial value (EPPO, 2008). The tomato leaf miner, Tuta invaded Egypt in the nearest Governorate to Libya (Marsa Mtrooh) in 2009. By 2010 it had reached Giza, coming 
well established in all Governorates of Egypt and reaching the border and north part of Sudan on June 2011 (Tamerk, 2011 \& Gaffar, 2012). Biological control has been developed and widely applied in different countries such as several South American states, using the oophagous Trichogramma parasitoids. Three different species of Trichogramma evaluated for reducing the number of $T$. absoluta eggs in Fayoum Governorate, Egypt (Gaffar, 2012). The sex pheromone of T. absoluta was identified in the late 1990 's and pheromone blends were subsequently tested aiming their use for field monitoring and mass trapping (Ferrara et al., 2001). Azadirachtin has been recommended for use as a preventive spray and for light infestations of $T$. absoluta in Spain (Van Deventer, 2009). Bio-insecticide, Bacillus thuringiensis exhibited a medium to low efficiency on all instars of $T$. absoluta. Azadiractin exhibits extremely low acute mammalian toxicity but it is very effective as control agent for many insect groups (Champagne et al., 1989). Shakeri and Foster (2007) reported that, Trichoderma harzianum used as Alcohols Antibiotics Biocontrol Enzymes Insect control Pathology Entomopathogens Insect pathogens. The prevailing situation is globally assessed and the impact on production of healthy crops through the adoption of an Integrated Production and Protection (IPP) approaches is discussed (Papasolomontos, 1998). The environmental conditions are factors influencing insect physiology and behavior. According to Zalom and Wilson (1982) the rate of development is based on the accumulation of heat measured in physiological rather than chronological time. population of the Tuta absoluta in Qena governorate gave the highest number of generation as compared to other locations (EL Beheira, Giza and Fayoum governorates) under climate conditions (Abolmaaty et al., 2010).

The objective of this study is to evaluate different control strategies including insecticide alternatives methods to control T. absoluta in open field, and calculate the quantity of production and the costs of control for each treatment during Spring and Summer plantation 2012.

\section{MATERIALS AND METHODS}

\section{Materials used:}

Alternative approaches used with integrated method to control Tuta absoluta, namely:

A. Synthetic sex pheromones of the tomato leaf miner, T. absoluta : $3 \mathrm{E}, 8 \mathrm{E}$, $11 \mathrm{Z}-14 \mathrm{AC}(\mathrm{C} 16 \mathrm{H} 26 \mathrm{O} 2),(\mathrm{E}, \mathrm{Z}, \mathrm{Z})$ - 3, 8, 11 - Tetradecatrienyl acetate obtained from Koppert Biological system company. 


\section{B. Microbial insecticides:}

\section{B. 1. Microbial entomopathogenic bacteria:}

Trade name: $B t$, and active ingredient: Bacillus thuringiensis var. kurstaki. was adjusted to be contain $33 \times 10^{6}$ C.F.U/1ml and obtained from Central Laboratory of Organic Agriculture, CLOA/Agriculture Research Center, ARC.

Rate of application: $4800 \mathrm{ml} /$ feddan.

\section{B. 2. Microbial entomopathogenic fungi:}

Trade name: Blightstop, and active ingredient: Trichoderma harzianum preparation contains $30 \times 10^{6}$ C.F.U/1ml obtained from Central Laboratory of Organic Agriculture, CLOA/ Agriculture Research Center, ARC.

Rate of application: $3600 \mathrm{ml} / \mathrm{feddan}$.

\section{C. botanical extracts:}

Trade name: Nimbecidine and active ingredient: Azadirachtin $0.03 \%$, and found in plant extract Neem tree (Azadirachta indica A. Juss.) oil obtained from GaaraEstablishment.

Rate of application: $2880 \mathrm{ml} /$ feddan

\section{Egg parasitoid, Trichogramma evanescens West.:}

The egg parasitoid, Trichogramma evanescens used for controlling T. absoluta was obtained from Plant Protection Research Institute, Agriculture Research Center, ARC. $70-75$ adult/ $\mathrm{m}^{2}$ were implemented according to (Gaffar, 2012 and Cabello et al., 2009). The rate of release for each treatment was 53400 individuals/release/712 $\mathrm{m}^{2}$, divided into 18 paper cards, each contained 3000 individuals, approximately. The parasitoid was released on 20/03/2012, 29/03/2012, 09/04/2012 and 18/04/2012 as Spring plantation and on 27/04/2012, 06/05/2012, 15/05/2012 and 24/05/2012 as Summer plantation during the year of 2012.

\section{Treatments for field experiments:}

Seven treatments (A, B, C, D, E, F and untreated) served to carry out different experiments to compare efficacy of the tested six integrated programs for controlling T. absoluta, namely Bacillus thuringiensis + Neem, B. thuringiensis + Trichogramma evanescens + mass trapping, $B$. thuringiensis + Trichoderma harzianum, T. harzianum + Neem, T. harzianum + mass trapping, T. evanescens + Neem and control, respectively. Each treatment was planted with 933 tomato seedlings ( $=5600$ plants/feddan). Where, the corresponding general means of spray reached $800 \mathrm{ml} \mathrm{Bt}+480 \mathrm{ml} \mathrm{Neem} / 80 \mathrm{~L}$. water, $800 \mathrm{ml} \mathrm{Bt/80} \mathrm{L}$. water +53400 individuals Trichogramma parasitoid, $800 \mathrm{ml} \mathrm{Bt}+600 \mathrm{ml} \mathrm{T}$. harzianum/80 L. water, $600 \mathrm{ml}$ T. harzianum $+480 \mathrm{ml} \mathrm{Neem} / 80 \mathrm{~L}$. water, $600 \mathrm{ml} \mathrm{T.} \mathrm{harzianum} / 80 \mathrm{~L}$. water + 53400 individuals Trichogramma parasitoid and $480 \mathrm{ml} \mathrm{Neem} / 80$ L. water +53400 individuals Trichogramma parasitoid and control. 


\section{Field experiments:}

Field experiments were carried out in a private farm in Baltiem district, KafrelSheikh Governorate, Egypt, during two successive tomato plantations, Spring in Murtada village, Kafrel-Sheikh district and Summer in Al-Chehabia village, Baltiem district plantations of 2012. In both plantations an area $4912 \mathrm{~m}^{2}$ was cultivated with tomato (Developed orient variety) on March $20^{\text {th }}$. The experimental area was divided to plots, each of $712 \mathrm{~m}^{2}$. The completely randomized block design was utilized in the initiated experimental traits with four replicates for each treatment $(=25$ leave/replicate) as well as the untreated check. Each plot was separated from the adjacent one by half-meter belt to minimize the interference of spray drift from one treatment to another. According to the complete randomized blocks, the experimental area ( 1 feddan), beside untreated check plot (1/6 feddan). 20 liters volume sprayer was used for microbial insecticides and botanical extracts spraying. Each bio-product was sprayed fourth times on 20/03/2012, 29/03/2012, 09/04/2012 and 18/04/2012 as Spring plantation and on 27/04/2012, 06/05/2012, 15/05/2012 and 24/05/2012 as Summer plantation during the year of 2012 . The evaluation of the control methods based on reduction percentages in infestation was determined according to the method adopted by Henderson and Tilton (1955).

\section{Estimation of degree-days units:}

\subsection{Under current climate temperature:}

For estimating degree day's unit (DDU), the daily temperature records were obtained from Central Laboratory for Agriculture Climate (CLAC) during the period from 01 January 2012 to 30 June 2012 for the experimental location (Baltiem district, Kafrel-Sheikh Governorate) and the average were calculated to determine number of generations for this pest during the period of experimental.

4.2. Determination of T. absoluta thermal units:

Maximum and minimum degrees of temperature were transformed to heat units using the lower threshold temperature (T0) $8^{\circ} \mathrm{C}$ with 460 (DDU) for T. absoluta development Barrientos et al., (1998). Degree day's unit calculations were made to estimate the number of possible generations of $T$. absoluta in the field using the following formula:

DDU $=($ Max. Mean Temp. + Min. Mean Temp. $) / 2-$ Min. Development Temp.

For T. absoluta the minimum threshold for the a development from egg to adult is $8^{\circ} \mathrm{C}$ and 460 DDU (Barrientos et al., 1998).

\section{Statistical analysis:}

The data was subjected to analysis of variance (ANOVA) and the means were compared by L.S.D. test at 0.05 levels, using SAS program (SAS Institute, 1988). 


\section{RESULTS AND DISCUSSION}

Comparisons between the different control methods were carried out on the basis of the reduction percentages in tomato leafminer, T. absoluta larvae infested tomato, Lycopersicon esculentum Mill. Vegetable plant on basis of reduction percentages in larval infestation:

The experimental trials were implemented to evaluate the role of different methods in controlling $T$. absoluta larvae infested tomato in Spring and Summer plantation during the year, 2012. The control methods used in current study included synthetic sex pheromones (pheromone baited traps), egg parasitoids T. evanescens, microbial insecticides and botanical extracts used in integration with Delta traps to monitor population levels and reduce the male Tuta moths population. The results were recorded as reduction percentages. The experimental results of Spring plantation are indicated in Table (1).

The obtained results from Spring plantation represented in Table (1) showed that all the control methods had highly reduction percentages over $90 \%$ after 10 days

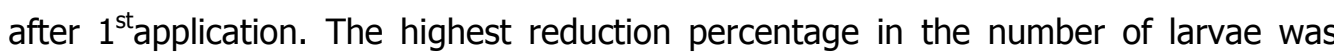
occurred in case of using entomopathogenic bacteria, $B$. thuringiensis combined with botanical extract, Neem. On the other hand, using entomopathogenic fungi, $T$. harzianum combined with mass-trapping of the pest male moths caused the lowest reduction percentage in infestation by larvae as compared with the other control measures.

As shown in Table (1) the general mean reduction percentage in the number of larvae during Spring plantation were 88.49, 86.03, 84.78, 83.01, 79.88 and $82.82 \%$ in treatments of Bacillus thuringiensis + Neem, B. thuringiensis + Trichogramma evanescens + mass trapping, $B$. thuringiensis + Trichoderma harzianum, T. harzianum + Neem, T. harzianum + mass trapping and T. evanescens + Neem, respectively. Data of Summer plantation as shown in Table 2 proved that the application of the previous control methods were more effective in reducing the larval infestation of tomato plants than that in Spring plantation. Similar trend associated to the efficacy of the previous control methods was noticed between Spring and Summer plantations.

Generally, using entomopathogenic bacteria, B. thuringiensis combined with botanical extract, Neem exhibited the highest reduction percentage in the number of larvae, where using entomopathogenic fungi, T. harzianum combined with masstrapping recorded lowest reduction percentage in the number of larvae during the two seasons Spring and Summer plantations. 
Table 1. Efficacy of insecticidal alternatives against the tomato leafminer, Tuta absoluta on tomato plants during Spring plantation in Murtada village, 2012.

\begin{tabular}{|c|c|c|c|c|c|c|}
\hline \multirow{2}{*}{$\begin{array}{l}\text { Period after } \\
\text { applications } \\
\text { (days) }\end{array}$} & \multicolumn{6}{|c|}{$\%$ Reduction in the numbers of larvae at indicated treatments } \\
\hline & A & B & C & D & $\mathrm{E}$ & $\mathrm{F}$ \\
\hline \multicolumn{7}{|c|}{$1^{\text {st }}$ application } \\
\hline 2 & 92.70 & 92.98 & 85.70 & 89.47 & 87.72 & 97.72 \\
\hline 5 & 96.01 & 95.01 & 97.04 & 97.02 & 95.0 & 98.02 \\
\hline 7 & 97.69 & 97.69 & 98.46 & 93.08 & 91.54 & 88.98 \\
\hline 10 & 99.15 & 94.07 & 94.07 & 89.83 & 88.32 & 81.54 \\
\hline Mean & 96.39 & 95.79 & 93.82 & 92.35 & 90.65 & 91.57 \\
\hline \multicolumn{7}{|c|}{$2^{\text {nd }}$ application } \\
\hline 2 & 96.43 & 91.07 & 86.61 & 82.14 & 91.07 & 86.01 \\
\hline 5 & 90.77 & 90.77 & 89.25 & 89.23 & 84.62 & 90.77 \\
\hline 7 & 89.17 & 90.74 & 88.89 & 85.19 & 77.22 & 79.17 \\
\hline 10 & 86.39 & 79.17 & 81.94 & 80.55 & 72.22 & 73.61 \\
\hline Mean & 90.69 & 87.94 & 86.67 & 84.22 & 81.28 & 82.39 \\
\hline \multicolumn{7}{|c|}{$3^{\text {rd }}$ application } \\
\hline 2 & 89.02 & 86.15 & 78.78 & 88.31 & 80.95 & 82.39 \\
\hline 5 & 86.17 & 80.59 & 84.81 & 78.90 & 77.72 & 85.28 \\
\hline 7 & 78.83 & 79.56 & 84.66 & 77.37 & 73.36 & 84.39 \\
\hline 10 & 74.87 & 75.94 & 72.73 & 70.59 & 62.57 & 75.55 \\
\hline Mean & 82.22 & 80.56 & 80.25 & 78.79 & 73.65 & 67.91 \\
\hline \multicolumn{7}{|c|}{$4^{\text {th }}$ application } \\
\hline 2 & 84.51 & 85.21 & 83.30 & 81.29 & 79.58 & 80.28 \\
\hline 5 & 85.93 & 82.96 & 83.70 & 82.22 & 76.29 & 80.74 \\
\hline 7 & 81.48 & 79.63 & 75.93 & 74.07 & 72.22 & 75.93 \\
\hline 10 & 70.75 & 71.43 & 70.07 & 68.71 & 65.99 & 67.55 \\
\hline Mean & 84.67 & 79.81 & 78.38 & 76.67 & 73.52 & 76.13 \\
\hline $\begin{array}{c}\text { General } \\
\text { mean }\end{array}$ & $88.49^{a}$ & $86.03^{a b}$ & $84.78^{b c}$ & $83.01^{c}$ & $79.88^{d}$ & $82.82^{c}$ \\
\hline $\mathrm{F}$ & \multicolumn{6}{|c|}{13.59} \\
\hline L.S.D. 0.05 & \multicolumn{6}{|c|}{2.4817} \\
\hline \multicolumn{7}{|c|}{$\begin{array}{l}\mathrm{A}=\text { Bacillus thuringiensis }+ \text { Neem } \\
\mathrm{B}=B . \text { thuringiensis }+ \text { Trichogramma evanescens }+ \text { mass trapping } \\
\mathrm{C}=B . \text { thuringiensis }+ \text { Trichoderma harzianum } \\
\mathrm{D}=T . \text { harzianum }+ \text { Neem } \\
\mathrm{E}=T . \text { harzianum }+ \text { mass trapping } \\
\mathrm{F}=T . \text { evanescens }+ \text { Neem }\end{array}$} \\
\hline
\end{tabular}

Based on general mean of reduction percentages in the number of larvae, the efficacy of the tested treatments could be descendingly arranged as follows Bacillus thuringiensis + Neem, B. thuringiensis + Trichogramma evanescens + mass trapping, B. thuringiensis + Trichoderma harzianum, T. harzianum + Neem, T. 
Table 2. Efficacy of insecticidal alternatives against the tomato leafminer, Tuta absoluta on tomato plants during Summer plantation in Kafrel-Sheikh district, 2012.

\begin{tabular}{|c|c|c|c|c|c|c|}
\hline \multirow{2}{*}{$\begin{array}{l}\text { Period after } \\
\text { applications } \\
\text { (days) }\end{array}$} & \multicolumn{6}{|c|}{$\%$ Reduction in the numbers of larvae at indicated treatments } \\
\hline & A & B & C & D & $\mathrm{E}$ & $\mathrm{F}$ \\
\hline \multicolumn{7}{|c|}{$1^{\text {st }}$ application } \\
\hline 2 & 94.44 & 91.67 & 91.05 & 86.56 & 84.11 & 83.33 \\
\hline 5 & 97.01 & 93.12 & 92.12 & 88.86 & 87.39 & 85.71 \\
\hline 7 & 98.06 & 95.17 & 89.36 & 91.13 & 88.03 & 90.62 \\
\hline 10 & 93.62 & 94.94 & 86.02 & 87.76 & 79.19 & 86.12 \\
\hline Mean & 95.78 & 93.73 & 89.66 & 88.58 & 84.68 & 86.45 \\
\hline \multicolumn{7}{|c|}{$2^{\text {nd }}$ application } \\
\hline 2 & 93.05 & 91.39 & 92.67 & 90.16 & 88.05 & 89.17 \\
\hline 5 & 92.71 & 92.52 & 90.29 & 86.29 & 85.78 & 85.19 \\
\hline 7 & 90.54 & 90.03 & 85.91 & 84.99 & 82.41 & 82.18 \\
\hline 10 & 91.32 & 87.97 & 83.89 & 82.89 & 78.91 & 80.01 \\
\hline Mean & 91.91 & 90.48 & 88.19 & 86.09 & 83.79 & 84.14 \\
\hline \multicolumn{7}{|c|}{$3^{\text {rd }}$ application } \\
\hline 2 & 91.55 & 88.17 & 87.55 & 85.11 & 82.99 & 85.34 \\
\hline 5 & 92.29 & 90.13 & 91.29 & 88.29 & 79.79 & 86.24 \\
\hline 7 & 87.61 & 86.25 & 85.15 & 86.14 & 75.96 & 84.05 \\
\hline 10 & 85.29 & 80.59 & 78.02 & 77.93 & 70.02 & 76.39 \\
\hline Mean & 89.19 & 86.29 & 85.50 & 84.37 & 77.18 & 83.01 \\
\hline \multicolumn{7}{|c|}{$4^{\text {th }}$ application } \\
\hline 2 & 93.94 & 91.95 & 91.67 & 83.18 & 83.11 & 82.02 \\
\hline 5 & 92.97 & 91.89 & 92.17 & 90.43 & 80.06 & 86.36 \\
\hline 7 & 88.99 & 89.85 & 86.14 & 81.19 & 76.12 & 82.11 \\
\hline 10 & 86.59 & 87.19 & 82.88 & 80.05 & 70.03 & 79.19 \\
\hline Mean & 90.62 & 90.22 & 88.22 & 83.71 & 77.33 & 82.42 \\
\hline General mean & $91.88^{a}$ & $90.18^{a}$ & $87.89^{b}$ & $85.69^{c}$ & $80.75^{d}$ & $84.01^{c}$ \\
\hline $\mathrm{F}$ & \multicolumn{6}{|c|}{38.94} \\
\hline L.S.D. 0.05 & \multicolumn{6}{|c|}{2.0384} \\
\hline
\end{tabular}

$A=$ Bacillus thuringiensis + Neem

$\mathrm{B}=\mathrm{B}$. thuringiensis + Trichogramma evanescens + mass trapping

$\mathrm{C}=\mathrm{B}$. thuringiensis + Trichoderma harzianum

$\mathrm{D}=\mathrm{T}$. harzianum + Neem

$\mathrm{E}=T$. harzianum + mass trapping

$\mathrm{F}=T$. evanescens + Neem

harzianum + mass trapping and $T$. evanescens + Neem. The corresponding value were $91.88,90.18,87.89,85.69,80.75$ and $84.01 \%$, respectively.

\section{Comparisons on basis of the controlling index and potency levels:}

It seems always convenient to consider the efficacy on the degree of controlling the target pest by different control agents via comparing them with a standard agent. In the present work, comparisons among the tested control methods are based on both control index method developed by Sun (1950) and the potency levels expressed as number of folds frequently used in this respect. 
Table 3. Relative comparison between insecticidal alternatives for controlling the tomato leafminer T. absoluta.

\begin{tabular}{|l|c|c|c|c|c|c|}
\hline \multirow{2}{*}{ Treatments used } & \multicolumn{2}{|c|}{$\begin{array}{c}\text { \% General reduction } \\
\text { during }\end{array}$} & \multicolumn{2}{c|}{ Control index * during } & \multicolumn{2}{c|}{ Potency level ** during } \\
\cline { 2 - 7 } & Spring & Summer & Spring & Summer & Spring & Summer \\
\hline Bt+ Neem & 88.49 & 91.88 & 100 & 100 & 1.11 & 1.14 \\
\hline $\begin{array}{l}B t+ \\
\text { Trichogramma + } \\
\text { trap catches }\end{array}$ & 86.03 & 90.18 & 97.22 & 98.15 & 1.08 & 1.12 \\
\hline $\begin{array}{l}\text { Bt+ Trichoderma } \\
\text { Trichoderma + }\end{array}$ & 84.78 & 87.89 & 95.81 & 95.66 & 1.06 & 1.09 \\
\hline Neem & 83.01 & 85.69 & 93.81 & 93.26 & 1.04 & 1.06 \\
\hline $\begin{array}{l}\text { Trichoderma + } \\
\text { trap catches }\end{array}$ & 79.88 & 80.75 & 89.28 & 87.89 & 1.00 & 1.00 \\
\hline $\begin{array}{l}\text { Neem + } \\
\text { Trichogramma }\end{array}$ & 82.82 & 84.01 & 92.68 & 91.43 & 1.04 & 1.04 \\
\hline
\end{tabular}

$*$ Control index $=\frac{\% \text { General reduction in the tested treatment }}{\% \text { General reduction in the most promising treatment }} \times 100$
$\% *$ General reduction in the tested treatment
$\%$ General reduction in the least effective treatment

On the ground of control index as illustrated in Table (3), the efficacy of the tested control methods, i.e. $B t$ integrated with $T$. evanescens and mass trapping of $T$. absoluta male moth, Bt integrated with T. harzianum, T. harzianum integrated with Neem, T. harzianum integrated with mass trapping of $T$. absoluta male moth and Neem integrated with $T$. evanescens recorded 97.22, 95.81, 93.81, 89.28 and $92.68 \%$, respectively as effective to $B t$ integrated combined with Neem against $T$. absoluta larvae during Spring plantation and 98.15, 95.66, 93.26, 87.89 and $91.43 \%$ as efficient as to $B t$ combined with Neem during summer plantation.

Concerning the potency level expressed as number of folds (Table 3), the efficacy of the tested control methods, i.e. Bt combined with Neem, Bt combined with $T$. evanescens and mass trapping of $T$. absoluta male moth, Bt combined with $T$. harzianum, T. harzianum combined with Neem and Neem integrated with $T$. evanescens recorded $1.11,1.08,1.06,1.04$ and 1.04 times, respectively as effective as $T$. harzianum integrated with mass trapping of $T$. absoluta male moth against the pest larvae during Spring plantation compared with 1.14, 1.12, 1.09, 1.06 and 1.04 times, respectively as effective as $T$. harzianum integrated with mass trapping of $T$. absoluta male moth against the pest larvae during Summer plantation. 
Results in Table (4) showed the relationship between population of $T$. absoluta male moths captured in sex attractant baited traps and accumulative heat unit in degrees-days (DD'S) during two plantations, Spring and Summer in 2012. As illustrated in Table (4) the population density of the male moths was increased gradually to reach the reliable occurrence of the $1^{\text {st }}$ generation during the last week of March in Spring plantation and first week of May in Summer plantation. The peak of this generation was recorded on March, $26^{\text {th }}$ and May, $3^{\text {rd }}$. The corresponding total number of the captured moths were 219 and 112.5 moths/3 traps/3days,respectively, where the accumulative heat units equal 409.02 and 851.22 degrees-days, respectively. After this period the reliable occurrence of the $2^{\text {nd }}$ generation of the pest took place in the first week of April and first May to reach its peak on April, $4^{\text {th }}$ and May, $8^{\text {th }}$. The corresponding total numbers of the captured moths of this peak recorded 435 and 264 male moths/3 traps/3days where the accumulative heat units equal 491.62 and 924.72 degrees-days, respectively. The population density of the male moths decreased in April $9^{\text {th }}$ and increased gradually from April $11^{\text {th }}$ to April $15^{\text {th }}$. In the half of April to reach its peak on April, $15^{\text {th }}$ and May, $19^{\text {th }}$. The corresponding numbers of captured male moths of this peak recorded 300 and 327 male moths/3 traps/3days when the accumulative heat units equal 636.72 and 1100.27 degreesdays, respectively. After this period, the population density of the pest was increased to reach its peak on April, $22^{\text {nd }}$ and May, $28^{\text {th }}$. The trapped moths recorded 360 male moths/3 traps/3days when the accumulative heat units equal 717.22 and 1244.87 degrees-days, respectively. As noticed in Table (4) the total numbers of captured male moths were higher in Spring plantation which reached 3996 male moth than that of those during Summer plantation which being 3040.5 male moths/3 traps/3days during the whole season. And the highest relative percentage number of captured moths were 10.91 and $10.76 \%$ in Spring and Summer, respectively. Whereas the lowest relative percentage number of captured moths recorded 2.86 and $2.71 \%$ in Spring and Summer, respectively.

Data shown in Table (5) demonstrated the highest yield production, price of production and cost benefit in Summer plantation recorded in case of using the control method, entomopathogenic bacteria, B. thuringiensis combined with botanical extract, Neem. On the other hand, using botanical extract, Neem integrated with egg parasitoids, T. evanescens gave the lowest healthy yield production, price of production and cost benefit. The correspondent value of yield production, price of production and cost benefit were 9.555 ton/feddan, 3822 L.E/feddan and 3317 L.E/feddan, respectively. The correspondent value of yield production, price of yield and cost benefit were 5.580 ton/feddan, 2230 L.E/feddan and 1835 L.E/feddan. 
Table 4. Population size of the tomato leafminer, T. absoluta male moths monitored by baited sex pheromone traps in tomato fields in Kafrel- Sheikh Governorate during Spring and Summer plantations, 2012.

\begin{tabular}{|c|c|c|c|c|c|c|c|c|c|c|c|c|c|}
\hline \multicolumn{14}{|c|}{ Mean number of male moths/trap/day at indicated plantation dates } \\
\hline \multirow{2}{*}{ 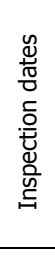 } & \multicolumn{4}{|c|}{ Spring } & \multirow[t]{2}{*}{$\begin{array}{l}\text { Inspectio } \\
\mathrm{n} \text { dates }\end{array}$} & \multicolumn{4}{|c|}{ Summer } & \multicolumn{2}{|c|}{$\begin{array}{c}\% \text { Relative No. } \\
\text { of captured } \\
\text { moths }^{*}\end{array}$} & \multicolumn{2}{|c|}{$\begin{array}{c}\text { Accumulative } \\
\text { heat units in } \\
\text { degrees-days } \\
\text { (DD's) }\end{array}$} \\
\hline & $\begin{array}{l}\text { Tra } \\
\text { p } 1\end{array}$ & $\begin{array}{l}\text { Tra } \\
\text { p } 2\end{array}$ & $\begin{array}{l}\text { Tra } \\
\text { p3 }\end{array}$ & $\begin{array}{c}\text { Tot } \\
\mathrm{al}\end{array}$ & & $\begin{array}{l}\text { Tra } \\
\text { p } 1\end{array}$ & $\begin{array}{l}\text { Tra } \\
\text { p2 }\end{array}$ & $\begin{array}{c}\text { Trap } \\
3 \\
\end{array}$ & Total & $\begin{array}{c}\text { Sprin } \\
\mathrm{g}\end{array}$ & $\begin{array}{c}\text { Summ } \\
\text { er }\end{array}$ & $\begin{array}{c}\text { Sprin } \\
\mathrm{g} \\
\end{array}$ & $\begin{array}{c}\text { Summ } \\
\text { er }\end{array}$ \\
\hline $\begin{array}{c}221 \\
3\end{array}$ & 78 & 62 & 70 & 210 & $29 / 4$ & 27 & 30 & 28.5 & 85.5 & 5.27 & 2.81 & $\begin{array}{c}376.7 \\
7 \\
\end{array}$ & 798.87 \\
\hline $\begin{array}{c}24 / \\
3 \\
\end{array}$ & 78 & 54 & 66 & 198 & $1 / 5$ & 32 & 24 & 28 & 84 & 4.97 & 2.76 & $\begin{array}{c}390.2 \\
7 \\
\end{array}$ & 824.12 \\
\hline $\begin{array}{c}26 / \\
3 \\
\end{array}$ & 66 & 80 & 73 & 219 & $3 / 5$ & 42 & 33 & 37.5 & 112.5 & 5.49 & 3.70 & $\begin{array}{c}409.0 \\
2 \\
\end{array}$ & 851.22 \\
\hline $\begin{array}{c}29 / \\
3 \\
\end{array}$ & 31 & 45 & 38 & 114 & $6 / 5$ & 22 & 33 & 27.5 & 82.5 & 2.86 & 2.71 & $\begin{array}{c}438.3 \\
2 \\
\end{array}$ & 896.47 \\
\hline $\begin{array}{c}31 / \\
3 \\
\end{array}$ & 60 & 66 & 63 & 189 & $8 / 5$ & 100 & 76 & 88 & 264 & 4.74 & 8.69 & $\begin{array}{c}450.6 \\
2 \\
\end{array}$ & 924.72 \\
\hline $2 / 4$ & 98 & 78 & 88 & 264 & $10 / 5$ & 52 & 64 & 58 & 174 & 6.62 & 5.72 & $\begin{array}{c}470.3 \\
7 \\
\end{array}$ & 955.72 \\
\hline $4 / 4$ & 134 & 156 & 145 & 435 & $12 / 5$ & 32 & 49 & 40.5 & 121.5 & 10.91 & 4.00 & $\begin{array}{c}491.6 \\
2 \\
\end{array}$ & 990.22 \\
\hline $9 / 4$ & 43 & 53 & 48 & 144 & $15 / 5$ & 71 & 34 & 52.5 & 157.5 & 3.61 & 5.18 & $\begin{array}{c}560.5 \\
2 \\
\end{array}$ & $\begin{array}{c}1053.7 \\
7 \\
\end{array}$ \\
\hline $\begin{array}{c}11 / \\
4 \\
\end{array}$ & 74 & 94 & 84 & 252 & $17 / 5$ & 86 & 58 & 72 & 216 & 6.32 & 7.11 & $\begin{array}{c}585.6 \\
2 \\
\end{array}$ & $\begin{array}{c}1070.0 \\
2 \\
\end{array}$ \\
\hline $\begin{array}{c}13 / \\
4 \\
\end{array}$ & 105 & 91 & 98 & 294 & $19 / 5$ & 90 & 128 & 109 & 327 & 7.38 & 10.76 & $\begin{array}{c}605.8 \\
7 \\
\end{array}$ & $\begin{array}{c}1100.2 \\
7 \\
\end{array}$ \\
\hline $\begin{array}{c}15 / \\
4 \\
\end{array}$ & 118 & 82 & 100 & 300 & $21 / 5$ & 87 & 103 & 95 & 285 & 7.52 & 9.37 & $\begin{array}{c}636.7 \\
2 \\
\end{array}$ & $\begin{array}{c}1131.6 \\
7 \\
\end{array}$ \\
\hline $\begin{array}{c}18 / \\
4 \\
\end{array}$ & 71 & 73 & 72 & 216 & $24 / 5$ & 78 & 66 & 72 & 216 & 5.42 & 7.10 & $\begin{array}{c}672.2 \\
2 \\
\end{array}$ & $\begin{array}{c}1179.2 \\
2 \\
\end{array}$ \\
\hline $\begin{array}{c}20 / \\
4 \\
\end{array}$ & 92 & 98 & 95 & 285 & $26 / 5$ & 75 & 96 & 85.5 & 256.5 & 7.15 & 8.44 & $\begin{array}{c}693.2 \\
2 \\
\end{array}$ & $\begin{array}{c}1211.2 \\
2 \\
\end{array}$ \\
\hline $\begin{array}{c}221 \\
4 \\
\end{array}$ & 128 & 112 & 120 & 360 & $28 / 5$ & 82 & 93 & 87.5 & 262.5 & 9.03 & 8.63 & $\begin{array}{c}717.2 \\
2 \\
\end{array}$ & $\begin{array}{c}1244.8 \\
7 \\
\end{array}$ \\
\hline $\begin{array}{c}24 / \\
4 \\
\end{array}$ & 99 & 95 & 97 & 291 & $30 / 5$ & 57 & 94 & 75.5 & 226.5 & 7.29 & 7.45 & $\begin{array}{c}738.5 \\
7 \\
\end{array}$ & $\begin{array}{c}1278.7 \\
2 \\
\end{array}$ \\
\hline $\begin{array}{c}27 / \\
4 \\
\end{array}$ & 71 & 73 & 72 & 216 & $2 / 6$ & 57 & 56 & 56.5 & 169.5 & 5.42 & 5.57 & $\begin{array}{c}775.0 \\
2 \\
\end{array}$ & $\begin{array}{c}1331.0 \\
6 \\
\end{array}$ \\
\hline $\begin{array}{c}\text { Tot } \\
\text { al }\end{array}$ & $\begin{array}{c}134 \\
6 \\
\end{array}$ & $\begin{array}{c}131 \\
2 \\
\end{array}$ & $\begin{array}{c}132 \\
9 \\
\end{array}$ & $\begin{array}{c}399 \\
6 \\
\end{array}$ & Total & 990 & $\begin{array}{c}103 \\
7 \\
\end{array}$ & $\begin{array}{c}1013 . \\
5\end{array}$ & $\begin{array}{c}3040 . \\
5 \\
\end{array}$ & 100 & 100 & $\begin{array}{c}775.0 \\
2 \\
\end{array}$ & $\begin{array}{c}1331.0 \\
6 \\
\end{array}$ \\
\hline
\end{tabular}

No. of captured moths

* Relative number of captured moths $=$ $\times 100$

Total No. of captured moths 
Table 5. Estimated yield production of tomato, control costs and cost benefit in the experimental trials of the different control methods during summer plantation, 2012.

\begin{tabular}{|c|c|c|c|c|c|c|}
\hline $\begin{array}{l}\text { Control } \\
\text { methods }\end{array}$ & $\begin{array}{l}\text { No. } \\
\text { of } \\
\text { trials }\end{array}$ & $\begin{array}{l}\text { yield } \\
\text { production } \\
\text { Ton/feddan }\end{array}$ & $\begin{array}{l}\text { Price of } \\
\text { production } \\
\text { L.E/feddan }\end{array}$ & $\begin{array}{l}\text { Control } \\
\text { costs } \\
\text { L.E/feddan }\end{array}$ & $\begin{array}{l}\text { Cost } \\
\text { benefit * }\end{array}$ & $\begin{array}{l}\text { Relative } \\
\text { cost } \\
\text { benefit } \\
\% * *\end{array}$ \\
\hline$B t+$ Neem & 4 & $9.555^{\mathrm{a}}$ & $3822^{a}$ & $505^{b}$ & $3317^{a}$ & 533.3 \\
\hline $\begin{array}{l}\text { Bt }+ \\
\text { Trichogramma } \\
+ \text { trap catches }\end{array}$ & 4 & $7.8007^{b}$ & $3120^{b}$ & $580^{c}$ & $2540^{c}$ & 408.4 \\
\hline $\begin{array}{l}\text { Bt }+ \\
\text { Trichoderma }\end{array}$ & 4 & $7.152^{c}$ & $2860.8^{c}$ & $250^{f}$ & $2610.8^{b}$ & 419.7 \\
\hline $\begin{array}{l}\text { Trichoderma } \\
+ \text { Neem }\end{array}$ & 4 & $6.851^{d}$ & $2740.4^{d}$ & $475^{d}$ & $2265.4^{d}$ & 364.2 \\
\hline $\begin{array}{l}\text { Trichoderma } \\
+ \text { trap catches }\end{array}$ & 4 & $5.988^{\mathrm{e}}$ & $2382^{\mathrm{e}}$ & $793^{a}$ & $1589^{f}$ & 255.5 \\
\hline $\begin{array}{l}\text { Neem }+ \\
\text { Trichogramma }\end{array}$ & 4 & $5.580^{f}$ & $2232^{f}$ & $397^{\mathrm{e}}$ & $1835^{\mathrm{e}}$ & 295 \\
\hline Untreated & - & $1.555^{\mathrm{g}}$ & $622^{g}$ & - & - & - \\
\hline $\mathrm{F}$ & & 1597.41 & 99999.99 & 13904.60 & 99999.99 & - \\
\hline L.S.D. 0.05 & & 0.1884 & 8.4194 & 4.6504 & 5.4832 & - \\
\hline
\end{tabular}

* Cost benefit $=$ price of the yield production in L.E /feddan - control cost in L.E/feddan.

** Relative cost benefit $\%=$ cost benefit in the treatments /price of the yield production of the untreated plot $\times 1$ 
Reviewing the previous results it could be concluded that $B$. thuringiensis had potential effect when integrated with Neem that increased the reduction in infestation rates with T. absoluta larvae. These results supported by FREDON-Corse (2009) which revealed $B$. thuringiensis var. Kurstaki (BtK) used for larval control, natural solutions of BtK applied to crops once per week at the end of the day and registered for use against T. absoluta larvae on tomatoes in the United States by (Sixmith, 2009). Data of the present study are in accordance with those recorded by Servicio de Sanidad Vegetal-Murcia (2008) which recommended for use Azadirachtin as a preventive spray and for infestation ( $\square 30$ adult catches per week) of $T$. absoluta in Spain. The study performed by Gaffar (2012), are agree with those obtained in this study. He carried out trials in Egypt to evaluate the augmentation releases of egg parasitoids, $T$. evanescens for controlling T. absoluta in greenhouses only is not strongly effective on tomato plants but, possibility to be used it in an IPM program.

\section{REFERENCES}

1. Abolmaaty, S. M., M. K. Hassanein, A. A. Khalil, A. F. Abou-Hadid, 2010. Impact of climatic changes in Egypt on degree day's units and generation number for tomato leaf miner moth Tuta absoluta, (Meyrick) (Lepidoptera: Gelechiidae). Nature and Science. 8(11): 122-129.

2. Barrientos, Z.R., H.J. Apablaza, S.A. Norero, and P. P. Estay, 1998. Threshold temperature and thermal constant for development of the South American tomato moth T. absoluta (Meyrick) (Lepidoptera: Gelechiidae). Ciencia e Investigacion Agraria. 25(3):133-137.

3. Cabello, T., J. R. Gallego, E. Vila, A. Soler, M. del Pino, A. Carnero, E. HernándezSuárez, and A. Polaszek, 2009. Biological control of the south American Tomato Pinworm, Tuta absoluta (Lep.: Gelechiidae), with releases Trichogramma achaeae (Hym.: Trichogrammatidae) in tomato greenhouses of Spain. IOBC/WPRS Bulletin. 49: 225-230.

4. Champagne, D. E., M. B. Isman, and G. H. Neil towers, 1989. Insecticidal activity of phytochemicals and extracts of the Miliaceae (Ini Arnason, J. T., Phiogene, B. J. R. and Morand, P. Eds., Insecticides of plant origin. A cs Symp. Ser. 387, Washington, D. C.).

5. EPPO, 2008. First report of Tuta absoluta in Spain. EPPO Reporting service no.1 2008-01-01.

http://www.eppo.org/PUBLICATIONS/reporting/reporting service.htm.

6. Ferrara, F. A. A., E. F. Vilela, G. N. Jham, A. E. Eiras, M. C. Picanco, A. B. Attygale, and J. Meinwald, 2001. Evaluation of the synthetic major component of 
the sex pheromone of Tuta absoluta (Meyrick) (Lepidoptera: Gelechiidae). Journal of Chemical Ecology. 27(5):907-917.

7. FREDON-Corse. 2009. Mesures de lutte contre Tuta absoluta. Fédération Régionale de Défense contre les Organismes Nuisibles de Corse. http://www.fredoncorse.com/standalone/1/CE5Bk98q7hNOOAd4q04sD67a.pdf

8. Gaffar, S. 2012. Relative comparison between parasitization efficiency of three Trichogramma species versus eggs of tomato leafminer moth, Tuta absoluta (Meyrick) on tomato greenhouse in Egypt. The Eleventh of Agricultural Development Research 27-30 March, 2012. Ain Shams Univ., Faculty of Agriculture. 168 -169.

9. Henderson, G. F. and E. W. Tilton, 1955. Tests with acaricides against the brown wheat mite. J. Econ. Entomol. 48: 157- 161.

10. Meyrick, E. 1917. Descriptions of South American Micro-Lepidoptera. Trans. Ent. Soc. London:1-52.

11. Papasolomontos, A. 1998. Integrated production and protection in the Mediterranean region under protected cultivation. Cahiers Options Méditerranéennes. 31: 413- 424.

12. SAS Institute, 1988. SAS/STAT Users Guide, ver. 6.30. SAS Institute Inc. Cry, Narolina.

13. Servicio de Sanidad Vegetal-Murcia. 2008. Control de la polilla del tomate (Tuta absoluta). Consejería de Agricultura y Agua.

14. Shakeri, J. and H. A. Foster, 2007. Proteolytic activity and antibiotic production by Trichderma harzianum in relation to pathogenicity to insects. Enzyme and Microbial Technology. 40 (4): 961-968.

15. Sixsmith, R. 2009. Call for integrated pest management as Mediterranean tomato pests spread to UK. Horticulture Week (October 9, 2009). Accessed November 5, 2009.

16. Sun, U. P., 1950. Toxicity index: an improved method of comparing the relative toxicity of insecticides. J. Econ. Entomol., 43: 45-53.

17. Tamerak, S. A., 2011. The status of $T$. absoluta in Egypt. EPPO/IOBC/FAO/NEPPO joint International Symposium on management of Tuta absoluta (tomato borer). Agadir, Morocco, November 16 - 18, 2011.18 pp.

18. Van Deventer, P. 2009. Leafminer threatens tomato growing in Europe. Agri- \& HortiWorld, Fruit \& Veg. Tech. $10-12$

19. WPTC, 2011. Report of World Processing Tomato Council, $10 \mathrm{pp}$.

20. Zalom, F., P. Goodell, L. Wilson, W. Barnett and W. Bentley, 1983. Degree-days: the calculation and use of heat unit in pest management. Division of Agricultural and Natural Resources, University of California, Davis, CA, USA. 10 pp. 


\section{إتجاهات حديثة لمكافحة آفة حافرة الطماطم فى حقول الطماطم فى مصر}

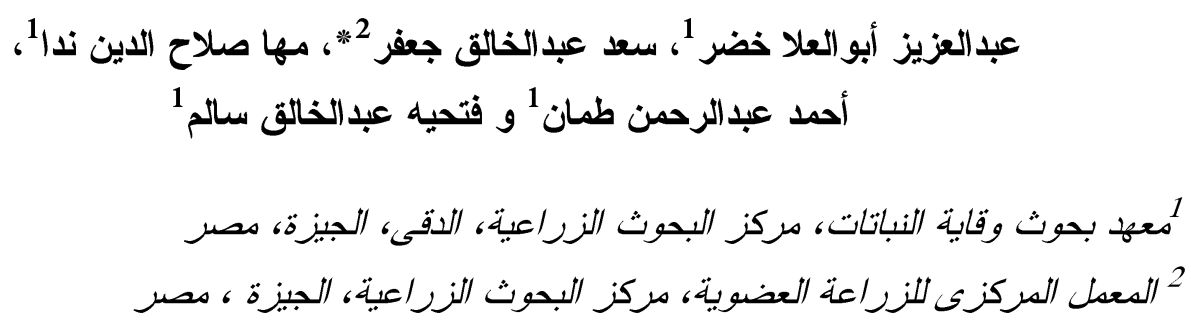

*Corresponding author. Email: saad_bio_organic@yahoo.com

يهدف هذا البحث إلى طرق مكافحة مختلفة بإستخدام بدائل المبيدات الحشرية وتشمل الفرمونات الجنسية (مصائد فرمونية) طفيليات بيض التريكوجر اما المبيدات الميكروبية و المستخلصات النباتية و التى استخدمت بالتكامل فيما بينها مع مصائد دلتا لإستكثاف مستوى التعداد

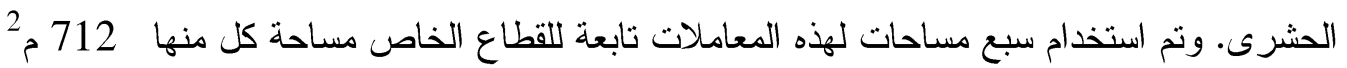
بمركز بلطيم بمحافظة كفر الثيخ لمكافحة هذه الآفة. نفذت طرق المكافحة بعدد اربع معاملات خلال

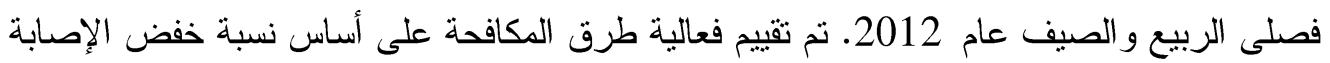
فى يرقات الآفة وذلك بعد فترات 2، 5، ك، 7 و و 10 يوم من كل معاملة. أوضحت النتائج زيادة نسبة خفض الإصابة فى العروة الصيفية مقارنة بفصل الربيع. كما أمكن نرتيب فعالية المعاملات تتازلياً

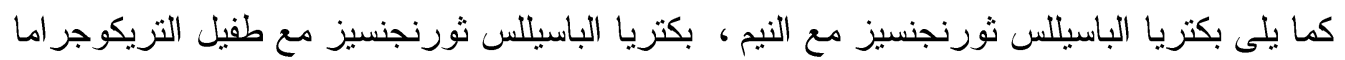

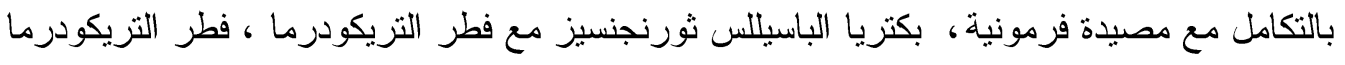
مع النيم، فطر التريكودرما مع مصيدة فرمونية و طفيل التريكوجر اما مع النيم. وسجلت القيم المقابلة

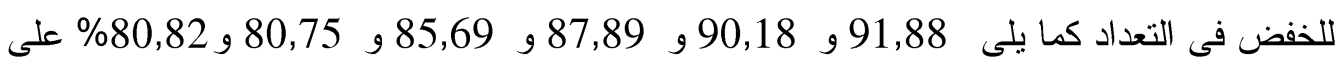
التوالى فى العروة الصيفية بينما كانت فى فصل الربيع كما يلى 88, 88,49 و 86, 86, و 84,78 و 83,01 و 79,88 و 82,82\% على التو الى. من ناحية أخرى سجل أستخدام المصائد الفرمونية لجذب ذكور الفر اشات بإستخدام الفرمونات الجنسية أعلى نسبة 10,91 و

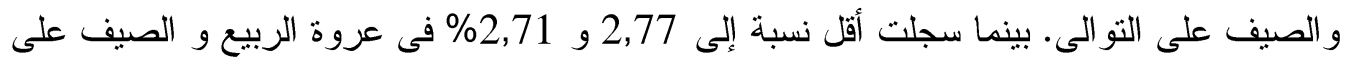

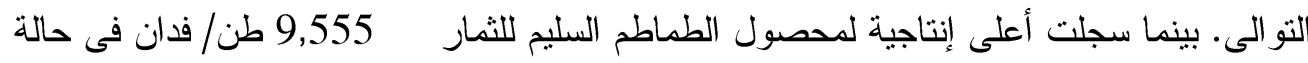
المكافحة بإستخدام بكتريا الباسيللس ثورنجنسيز و النيم فى حين سجلت أقل إنتاجية للإنتاج السليم

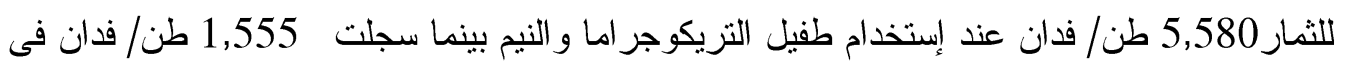
المساحات غير المعاملة. وكان أعلى صافى لعائد الربح 3317 جنيه مصرى عند المبند المعاملة بالمركب

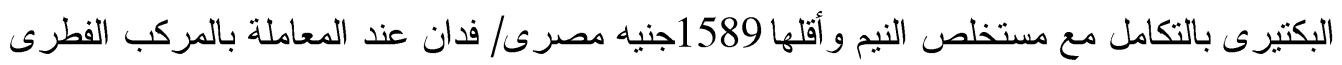
(التريكودرما) + إصطياد ذكور الفراثات. 